swab was taken, in four the pus grew staphylococci sensitive to ampicillin, and in two staphylococci insensitive to ampicillin were grown. Eleven grew coliform organisms; six of these were sensitive to ampicillin and the other five not.

Professor Garrod's conclusion that the failure of ampicillin in this series may have been due to the presence of resistant organisms seems to be supported by the present analysis. I regret it is not more complete.I am, etc.,

A. V. Pollock

Scarborough Hospital,

Yorks

1 Pollock, A. V., and Tindal, O. S., British foumal of Surgery, 1972, 59, 98.

\section{Causes of Failure in Antibiotic Treatment}

SIR,-Professor L. P. Garrod's article (25 November, p. 473) was both informative and interesting, with many important points relevant to current practical problems of antibiotic therapy.

One point needs clarification however. Professor Garrod affirms his strong belief that bacteristatic and bactericidal drugs in combination should always be avoided. Most bacteriologists would agree with him in principle, but a few necessary exceptions must be made. A well-established example of combined therapy with bactericidal and bacteristatic drugs is in the standard treatment of tuberculosis with streptomycin and isoniazid (both bactericidal) and PAS (bacteristatic).

Should not an exception also be made in the trearment of brucellosis, especially since co-trimoxazole has not proved to be as effective as was first hoped? 1 Richardson and Holt $^{2}$ have shown a degree of synergism in the action of streptomvcin and tetracycline (bacteristatic) on intracellular Brucella abortus in tissue culture, and clinically the cnmbination of stredtomvcin and tetracycline apdears to be the most effective treatment we have for brucellosis. ${ }^{3}$ Would Professor Garrod agree that brucellosis is another exception, or what trearment would he recommend for acute brucellosis? - I am, etc.

\section{J. S. Cargill}

Roval Infirmary,

Glasgow

\footnotetext{
1 Hassan, A., Erian, M. M., Farid, Z., Hathout, S. D., and Sorensen, K., British Medical fourmai, 1971, 3, 159

2 Richardson, $M$... and Holt, J. N., Fournal of Bacteriology, 1962, 84, 638.
3 Williams, B., Lancet, 1970, $2,604$.
}

\section{Infertility after the Pill}

SIR,-I agree with Mr. E. E. Philipp (4 November, p. 294) that the two or three-day hormonal tests for the diagnosis or exclusion of pregnancy are uncertain. They cause unnecessary delay with increasing risks to the patient if the question of termination is being considered. I would, however, not go as far as condemning the use of these preparations altogether.

In cases of amenorrhoea after the pill the possibility of a missed abortion may also have to be considered. A negative pregnancy test does not rule it out, but a negative pregnancy test after amenorrhoea of at least 6 weeks, followed by withdrawal bleeding after two to three days' administration of an oestrogen-progestogen preparation, exades a missed abortion and may be followed by resumption of regular menstrua cycles.-I am, etc.,

St. Leonards-on-Sea,

Bruce ETON

Sussex

\section{General Knowledge of Cancer}

SIR,-One welcomes a leading article on such a subject as "General Knowledge of Cancer" (18 November, p. 381) with comment on the valuable work carried out in Manchester with the support of the Department of Health and Social Security and in south-east Wales by the Tenovus Cancer Information Centre in Cardiff. It is a pity that you did not mention the latest publication of the Manchester survey, as Dr. John Wakefield has provided a masterly review of the social behaviour analysis in the Manchester region, and also that no comment was made on the other organizations which have done so much stalwart work in the field of publicity and health education.

What is more significant than the results given in your leading article is the fact that at long last the cancer research organizations and the D.H.S.S. are beginning to provide funds for this vital area of research into publicity, education, and the analysis of population response. For all too long cancer information and prevention organizations have had to manage on what they could obtain through meagre fund-raising efforts of their own, with an occasional donation from certain munificent or dedicated trusts. I refer especially to the Women's National Cancer Control Cam. paign, started in 1964, which now, with Si John Peel as president and Lady LlewelynDavies as chairman, is supporting screening programmes in numerous boroughs and counties with both static and mobile caravan clinics, and is providing a substantial programme of information, education, and the preparation of a population for a screening programme. It is only by proper preselection and preparation of the target population that prescriptive screening will achieve an acceptable priority in competing for the limited N.H.S. funds. But it is the multiple and varied approach to the different herd groups that creates the greater population response and the best economic result.

It is fortunate that such organizations as the W.N.C.C.C. and other more regional ones are now being taken under the wing of the Health Education Council and British Cancer Council, with direct financial support. It is to be hoped that these fund will increase in the future. With judicious control and advice these voluntary organzations wrill provide an inestimable service in the field of preventive disease.-I am etc.

O. A. N. Husann Medical Advisory Chairman, Women's National Cancer Contro

London W.C.2

\section{Corticosteroids in Retroperitoneal Fibrosis}

SIR,-Ureteric catheterization is necessary in most cases of retroperitoneal fibrosis both a a diagnostic step and for kidney drainage in renal obstruction. We report a case here which suggests that if corticosteroid therapy is given at the time of catheterization and maintained afterwards further surgical intervention for ureteric obstruction may be avoided. Opinions differ on whether corticosteroids can be a substitute for surgery or only adjunctive to it. ${ }^{1-7}$

A 68-year-old man was admitted to hospital complaining of lower abdominal discomfort and backache of eight week's duration. He had a persisting pyrexia, a raised E.S.R., and serum albumin of $2.3 \mathrm{~g} / 100 \mathrm{ml}$ in total serum proteins of $6.8 \mathrm{~g} / 100 \mathrm{ml}$. Anuria developed suddenly after 27 days. This responded at first to intravenous diuretics, but after 48 hours there was almost complete anuria and the blood urea, previously normal, rose to $230 \mathrm{mg} / 100 \mathrm{ml}$. The intravenous pyelogram appearances were compatible with bilateral ureteric obstruction. Cystoscopy and bilateral ureteric catheterization confirmed that the bladder was empty and a free flow of urine was obtained from both catheters. Anuria again developed when the catheters were withdrawn after 36 hours, and further drainage was necessary. Bilateral ureterolysis was performed a fortnight later, when the blood urea was $77 \mathrm{mg} / 100 \mathrm{ml}$. The patient was discharged after 24 days. He was passing urine normally, the blood urea was 23 $\mathrm{mg} / 100 \mathrm{ml}$, and the E.S.R. $4 \mathrm{~mm} / 1 \mathrm{hr}$.

Six months later he complained of feeling unwell and two months after that the E.S.R was $120 \mathrm{~mm} / 1 \mathrm{hr}$ and the blood urea $76 \mathrm{mg} / 100 \mathrm{ml}$. After ensuring that the urine was not infected, treatment with prednisolone $40 \mathrm{mg}$ daily was begun. Improvement in the subjective symptoms was dramatic and has been sustained for 14 months. During the past 10 months the maintainance dose of prednisolone has been $5 \mathrm{mg}$ twice daily. The E.S.R. is now $44 \mathrm{~mm} / 1 \mathrm{hr}$ and the blood urea $65 \mathrm{mg} / 100 \mathrm{ml}$.-We are, etc.

A. Apalakis J. K. MCCOLIUM

Newcastle General Hospital Newcastle-upon-Tyne

1 Ross, J. C., and Tinckler. L. F., British fouma of Surgery, 1958, 46. 58.

O Regan, R., Treahy, P. A., and Prior, I. A. M. New Zealand Medical foumal, 1961. 60, 518. Cew, C. K., Jarzylo, S. V.: and Valberg, L. S. 95,1183

Charlton, C. A. C., Proceedings of the Royal

Burberg G. Dine W. P. Surgery, Gynecology and Obstetrics, 1966, 123, 729.

Mitchinson, M. I., Withycombe, J. F. T., and Arden Jones, R., British fournal of Urology, 1971, 43, 444.

Morandi, L. P., and Grob. P. J.. Archives of Internal Medicine, 1971, 128, 295.

\section{Pulmonary Aspiration after Fibre-endoscopy}

SIR,-I was interested in the article (4 November, p. 269) entitled "Pulmonary Aspiration after Fibre-endoscopy of the Under Gastrointestinal Tract" by Drs. B. J. Prout and C. Metreweli and, in particular, in the technique of preparing the patient for the procedure.

The analgesic-sedative technioue used in this hospital for fibreoptic gastroscopy consists of conventional oremedication (pethidine and atropine) followed just before the procedure by an intravenous injection of a mixture containing 0.05-0.1 m of fentanyl and 5-10 $\mathrm{mg}$ of droperidol. This is followed by the intravenous injection of diazepam in a dosage sufficient to cause drowsiness, usually less 